\title{
Successful Growth Strategies of Three Chinese Domestic Hotel Companies
}

\author{
Yu Qin, Ph.D., Associate Professor \\ Head of Department of Hotel Management, School of Tourism Management, \\ Beijing International Studies University, \\ Beijing, China, 100024, PR China \\ E-mail: qinyu@bisu.edu.cn, qinyu.bisu@hotmail.com \\ Howard Adler, EdD. (Corresponding author) \\ C.B. Smith Professor of Hotel Management \\ Director, Center for the Study of Lodging Operations, Purdue University \\ School of Hospitality and Tourism Management \\ Marriott Hall, West Lafayette, Indiana 47906 \\ Tel: +1-765-494-5998Ｅ-mail: adlerh@purdue.edu \\ Liping A. Cai, Ph.D. Professor \\ Director, Purdue Tourism and Hospitality Research Center, Purdue University \\ School of Hospitality and Tourism Management \\ Marriott Hall, West Lafayette, Indiana 47906 \\ E-mail: liping@purdue.edu
}

Received: January 1, 2012

doi:10.5430/jms.v3n1p40

\author{
Accepted: February 2, 2012 Published: February 15, 2012 \\ URL: http://dx.doi.org/10.5430/jms.v3n1p40
}

\begin{abstract}
This paper explores the business level strategies implemented by the top three domestic Chinese lodging companies in the economy segment. Through interviews with the management of the three companies, the authors found the essential elements of their strategies were innovative positioning, keeping cost low, rapid expansion, continuous innovation, focus on quality consistency, extensive training and several indigenous Chinese cultural operational practices. Implications for future for research and practices are also discussed.
\end{abstract}

Keywords: Business level strategy, Hotel growth strategies, Low cost strategy, China indigenous operational practice, China domestic hotel companies

\section{Introduction}

Since the beginning of the new millennium, several Chinese domestic hotel companies, namely, Home Inn, Jinjiang Inn, Motel Chain and have achieved unprecedented growth and impressive performance. At the end of 2009, Home Inn had opened 621 hotels since it was founded in May 2002 which equates to adding on average one hotel to its portfolio every 5 days. Jinjiang Inns have expanded from 15 hotels in 2003 to 325 in 2009. Motel Chain built a 191-hotel network in a similar 7-year period. According to the Chinese Hotel Association (CHA), the occupancy rate of the three companies were also far higher than the average level of star-rated hotels, at above $80 \%$ for the three companies versus other star-rated hotels at $58.30 \%$. Some well-established domestic companies such as BTG-Jianguo and JinLin Hotels \& Resorts, which have both been immersed in the hotel industry for more than 25 years, were overwhelmed by the three new companies in recent years (Table 1).

$<$ Table 1 about here $>$ 
Given the amazing growth results of the three companies, there is very little academic research so far aimed at analyzing and explaining the success of these hotel chains. The three companies could not grow so fast without employing successful strategies. The purpose of this study is trying to explain the success story of the three hotel chains by studying their business level strategy through a case research method. Specifically, the focus is on answering one question: What were the business level strategies pursued by the three companies?. The results of this research will aid other companies and future companies in reviewing business level strategies which have been successful in this fast growing segment of the lodging industry in China. It is hoped that these strategies can than be used for benchmarking and best practices.

\section{Review of the Literature}

\subsection{Business Level Strategy Research in the Hospitality Industry}

According to Ansoff (1965), business strategy is a method of business competition which involves choices about how to compete within a given industry. Schendel and Hofer(1979) also indicated business level strategy copes with the question "How should a business position itself among its rivals in order to achieve its goals?”. Galbraith and Schendel (1983) presented a list of the typologies of business level strategy. There have only been a few research studies aimed at business level strategy in the hospitality area. There are two popular hospitality strategy textbooks which include business level strategy. The main competition strategy research related to the hospitality industry has concentrated on competition interaction (Baum \& Haveman, 1997, Baum \& Ingram, 1998, Baum \& Mezias, 1992, Ingram \& Baum, 1997, Ingram \& Inman, 1996), critical success factors(Brotherton, 2004, Brotherton \& Shaw, 1996, Geller, 1985), global strategy (Whitla, Walters, \& Davies, 2007) and marketing strategy (Dev \& Brown, 1990, Meidan \& Lee, 1982).

Several scholars have examined business level strategies in the hospitality industry using Porter's generic strategic framework. Schaffer (1987) tested the relationship between structure and strategy of hotel organizations and the characteristics of competitive strategies in the lodging industry (Schaffer, 1987, Schaffer, 1984, Schaffer, 1986). West and Anthony(1990) examined the strategies of 65 restaurants' and classified them into five strategic groups. Dev (1989), and Claver, Molina, \& Pereira, 2007), and Wong and Kwan(2001) also investigated competitive strategies in different settings. Their research introduced and applied mainstream strategic theory to the hospitality industry. However, their main focus was to explore the structure-strategy-performance relationship in the hospitality industry, rather than the strategy itself.

Most hospitality strategy research has focused on organizations in developed countries. Although some research has discussed business level strategy in a developing country context, most of it has focused on small and newly-industrialized economies like Hong Kong and Singapore, rather than huge developing countries like China and India. This research is a response to Canina's suggestion(2008) that research needed to be conducted on the expansion of the hotel industry in emerging economies such Brazil, Russian, India and China. It is also an attempt to explain and challenge current theories through a case study method, as also suggested by Combs (2008).

\subsection{Growth of Hotels in China}

Hotel chains in China have undergone tremendous changes since the government changed its policies in 1979 with the Open Door Policy. In 2001 the stock of accommodations in China stood at 10,400 properties and 945,000 rooms and by 2010 has nearly doubled (CNTA 2010). The increase in supply was driven partially by the growth in international arrivals which grew by $7 \%$ in 2010 alone. But the growth was also driven by Chinas own increasingly affluent population who are traveling more and more within their own country ( Pine \& Qi 2004). Both Chinese owned hotels and foreign owned hotels have great potential for future growth however the threat of oversupply remains a critical issue (Okoroafo 2010). Many companies have been induced to expand however many difficulties create conditions which either enhance or restrict the practicality and profitability of expansion.

Chinese companies have been playing catch up but have begun to adopt standard international hospitality practices combined with selective cultural adjustments to achieve necessary levels of growth (Okoroafo 2010). In the past many of the hotels were state owned and run and they did not feel the urgency to compete and improve their performance (Okoroafo 2010). Hotels in China operate under different ownership structures which include state-owned hotels, collective, private alliances, share holding cooperatives, foreign invested and Hong Kong, Macau and Taiwan invested to name a few (CNTA 2003)

A study by Pine and Qi in 2004 examined the formation and expansion of hotel chains in China. They found 4 main barrier to chain development which included the economic and political systems, the issue of hotel ownership, hotel management capability and resources and lastly competition between local and foreign firms. As the Chinese hotel industry continues to show significant growth hoteliers are making great progress in dealing with many of these issues. 


\section{Methodology}

This research was conducted using a qualitative methodology which was exploratory in nature and was designed to yield descriptive data in order to answer the questions advanced in the introduction section. The research follows Yin (1994) and other's suggestion (Barr, 2004, Eisenhardt \& Graebner, 2007, Gersick, 1994, Gersick, 1988, Ghauri, 2004, Miles \& Huberman, 1994) on applying a case study as the method. Specifically, the study uses a multiple case research design (Eisenhardt, 1989, 1989).

\subsection{Research Sample}

The researchers chose the top three companies in the booming economy hotel segment in China as the basis for this research (Table 2). The three companies are Home Inn, JinJiang Inn and Motel Chain. This three companies were selected since they are the biggest ones in this segment and the sample includes the first economy hotel brand (JinJiang Inn) in China plus the two companies which have grown most rapidly, Home Inn and Motel Chain. It is believed that the success of these companies is closely related to their business level strategies. Furthermore, all three companies promised the researcher the necessary assistance and cooperation to complete this research.

$<$ Table 2 about here $>$

To conduct the research a team consisting of two hotel management professors and eight graduate students was organized to execute the research plan. The research team collected extensive secondary data about the Chinese hotel market and about the three companies respectively. A comprehensive literature review focusing on the business level strategy, structure and competitive nature of the Chinese hotel market was completed. Questions were than identified for the forthcoming semi-structured interviews. Dozens of interviews were conducted in Shanghai with the majority were finished within a one month period of time. The exception was a telephone interview with the CEO of Home Inn after the company declared a key strategic decision.

\section{2 Data Collection}

With the assistance of hospitality and tourism graduate students, the researchers conducted interviews with the management teams (CEO, and/or COO, and the directors from key functional departments) of each company. The research team then interviewed eight hotel general managers from the three hotel company's.

All interviews used a semi-structured format and were recorded. There were two people at each interview, one asked questions and the other one took notes. After each interview, two graduate students listened to the recording and transcribed them into Word format. In total 26 individual interviews were conducted during the field work stage.

\subsection{Interviews}

\subsubsection{CEO/COO Interviews}

Interviews of 60 to 120 minutes in length were conducted with CEOs or COOs from Home Inn, JinJiang Hotel International, JinJiang Inn and Motel Chain in their headquarters during.

The researcher first asked the CEOs to introduce briefly the development history of their companies. Then they supplied a detail description of their opinions about the evolution of the Chinese hotel market and the core competencies and business level strategy pursued by their companies. The interviews examined questions like "what are the elements of business level strategy in your company?"'’s it a low-cost orientation strategy or a differentiation orientation one? "’'What are the underlying factors which support high-speed growth?"

\subsubsection{Directors Interviews}

Interviews were then conducted with directors from key functional departments, including Marketing, Operations, Finance and Human Resource. The researchers asked the directors to describe their understanding about the business level strategy their companies have pursued and the role their departments have played and will play in strategy implementation. The interviews lasted between 30 to 60 minutes.

\subsubsection{General Manager Interviews}

The research team also interviewed eight hotel general managers from the three companies in order to gather further information about the implementation of business level strategies. This information helped the researchers to better understand how these strategies were executed at the unit level. The average interview lasted 30 to 60 minutes with one 90 minutes exception.

\subsubsection{Direct Observation}

During time in Shanghai, the research team visited several hotels operated by the three hotel companies. Two Home Inn 
hotels, one JinJiang Inn hotel and two Motel Company hotels were visited by the research team. The team spent one or two nights at each hotel and ate at least one meal in each hotel. The team took notes on what they observed in each hotel including the building appearance, the design and facilities, layout and amenities of room and bathroom, restaurant, et al,. The research team also talked with front-line employees and customers to triangulate what was observed with what the researcher had been told.

\subsubsection{Secondary Data}

Secondary data was collected before the interview stage. The data included industry reports and industry news, financial reports, academic publications and archival data from China Hotel Association (CHA) and China Tourist Hotel Association (CTHA). The data collection activities extended to the interview stage where the research team got some internal publications and newsletters and lasted to the data analysis stage where the latest financial report of Home Inn was download as well as from CHA and CTHA. These data, accompanying with interview data and observation data, make data verification through triangulating possible (Ghauri, 2004, Stake, 2005).

\subsection{Data Analysis}

Following Eisenhardt (1989, 1989), Gersick (1994) and Miles and Huberman (1994), the researchers divided the data analysis process into three stages: data reduction, data display, and conclusion drawing.

At the reduction stage, the data was focused, simplified, abstracted the field notes and transcriptions, and transformed into concise information. After the transcripts and notes were reduced, the second task in the analysis was to display the data in an organized way as to draw some rudimentary conclusions regarding the business level strategy pursued by the three companies. Tables, charts and matrices were utilized to assemble reduced data into an immediately accessible, compact form (one excerpt is shown in Table 3). With the displayed data from observations, interviews and secondary sources, the similarities of the strategy patterns among the three companies were summarized.

The three stages were not independent and sequential but interdependent and interactive with each other. Data display, for example, was also a process of data reduction and some initial conclusions are also made when the data were displayed.

$<$ Table 3 about here $>$

\section{Findings}

The findings indicate that there were several common competitive strategies being practised by the three companies. They are innovative positioning, keeping costs low, expanding quickly, continuously innovating, highlight on quality and consistency and extensive training, plus some other indigenous operation practices.

\subsection{Innovative Positioning}

Innovative positioning was found to be one of the critical strategic factors responsible for the high-speed growth of the three companies. The three companies created a new niche through innovative positioning. The new niche, the economy hotel market, is a relatively underdeveloped market in China. When international hotel companies opened their first hotel in 1984, the Great Wall Sheraton Hotel in Beijing, multinationals, like InterContinental, Marriott, Starwood and Accor, crowded into the Chinese market. Most of their hotels are mid-to-upper-scale brand (Table 4). For local players, there are no competitive advantages when competing with multinationals in this segment. The only opportunity lies in the lower segment where there is no strong presence of international brands (Zhang, Qin, \& Li, 2001). Porter pointed out that the essence of strategy is "the creation of a unique and valuable position"(1996). This research found that the three companies all positioned themselves as an "affordable lodging product for Chinese people”, an ignored niche in China's hotel market. The Director of Marketing from Home Inn told stated that "inbound tourists are less than $1 \%$ of their customer pool and is not their target market. Up to now, we focus on domestic tourist."

\section{$<$ Table 4 about here $>$}

The three companies' innovative positioning is first reflected in how they name themselves. We found the names of the three companies are largely different from extant Chinese hotel companies. Jinjiang Inn's Chinese name, for example, is “Jinjiang Zhixing Lvguan company” rather than “Jinjiang Zhixing Binguan company” or “Jinjiang zhixing Jiudian company”. What's the main difference between Lvguan and Binguan or Jiudian? In Chinese, Binguan and Jiudian mean upscale hotel. Lvguan, by contrast, suggests low price, non-star-rated lodging property. Under this circumstance, name matters, as the COO from Jinjiang Inn mentioned,

"Why we use Lvguan rather than Binguan or Jiudian? Because we want to be a company which aimed at meeting the needs of mass tourists in China. Binguan make our customer think our hotels is above their daily 
living, -like a lady with a noble bearing, nevertheless, Lvguan make people feel folksy, -like a neighbor girl. So, we should degrade ourselves".

For the same consideration, Home Inn named itself inn, a word which has similar meaning with Lvguan in Chinese, rather than "Home Binguan”. Motel Chain uses a typical symbol Motel as its brand name, which also has the same meaning like Lvguan in Chinese.

The innovative product design is a main attraction for domestic traveler as its high value.

"We take economy as the core characteristic of Jinjiang Inn. It costs less, but it provides more value than star-rated hotels. Our CEO calls it as "yixing de qiang, erxing de tang, sangxing de fang, sixing de chuang” (The exterior features of our hotel looks like a 1-star hotel's, it's lobby looks like a 2-star hotel's, but the standards of rooms and bathrooms are not lower than that of 3-star hotel and the bed and beddings are as good as those in 4-star hotels )(COO, Jinjiang Inn)

In the similar way, the CEO of Home Inn, related the customer needs with product design and cost allocation,

"Home Inn is not a traditional hotel company. We have different modes. The key difference is we allocate our cost in accordance to the needs of our customer. In Home Inn, we did do something, but we did not do some other things".

Jian’s colleague, General Manager from Jixianglu interpreted his points more directly,

"Our facilities are simple but very practical. What we provide is actually that what the customer need. Does the mini-bar in the guestroom make the room look better? Of cause it does, but it costs more and most guests would not use it".

The three companies allocated most of their costs on the shower, towels, bedding, mattresses, writing desks and other amenities related to the guests' needs and feelings. In the same time, they removed most of the non-essential and expensive features like spacious lobbies, swimming pools, unnecessary restaurants, decorated exterior walls and carpeted floors. Being compared with traditional one-star and two-star hotels, the three companies created a totally different product which has lower costs and a higher value which satisfy their customers.

\subsection{Maintaining Low Costs}

Due to limited travel budget, most Chinese people can’t afford expensive hotel product. Even the upper class guests(around $5 \%$ of all urban population) were found as values seekers despite that they were identified as more brand conscious in the meantime (Cui \& Liu, 2001).In order to lower the price, the three companies executed low cost strategy which was mainly reflected in strict cost control and standard product design.

We found that the three companies applied the low cost strategy which was implemented by the chief executive first. In Home Inn, cost control is one top priorities of Top Management,

Cost control is always on my mind. It's growing in our blood and spirit from the frontline worker to the top management team and become a part of our culture. This is why all the offices of our TMT members are small and simple; why I have never flown by first class or business class; why I have always stayed overnight in Home Inn or other economy hotels instead of 5-star or 4-star hotels during business trip. (CEO, Home Inn)

Operation Director from Motel Chain has the same point,

Costs minimization is one of our top priorities. Electrician, for example, must know something about carpentry. In the rush hour, the general manager must serve the customer as a frontline worker.

As Mintzberg(1978) and Snow and Hambrick(1980) argued, there is a gap between the intended strategy and realized strategy. Some intended strategies conceived by TMT won't be realized for different kinds of reasons. In the three companies, we found that intended low cost strategies was realized though successful implementation in unit level. We have been told by the following general managers,

The security guards in our hotel were asked to learn how to clean the guestroom in case of manpower shortage in the rush hours or in late evening. (GM from Pudong store, Motel Chain)

Labor costs and energy costs are the top two costs in economy hotels. We have only 70 employees to operate this 239-room hotel. As one of the ways to control energy costs, we adjusted the switch on/off time of electric light in our public area according to the daylight change. (GM from Jinling store, Motel Chain)

Half of the light bulbs in the corridor will be switched off in the late night. (GM from Oujieju store, Home Inn) 
Keeping costs low is considered even before the hotel opens. One Motel Chain hotel in which we spent one night was transformed from a retailing market building. The company leased it from the owner and transformed it into a hotel without changing the mainframe. When doing that, the managers and architects racked their brains in finding a way to meet the regulation requirements from city planning department. It is really laborious work but it is worth the effort because the rent is only half of the market price for hotel leasing operation.

The three companies also developed standardized product. The furniture, the electronics, the amenities and the linens are the same across the same generation hotels (we will discuss the "generation" issue later). Standardized product improved the bargaining power of these companies when they negotiated with supplier, lowered the purchasing cost. For example, through Central Purchasing System or Area Purchasing System (which system will be used depends on what will be purchased), Motel Chain saved a lot and made their unit manager concentrating on more important issues rather than bargaining with all kinds of suppliers.

The headquarters supports us strongly in purchasing and logistics. Most supplies we need can be purchased through our headquarters. If we make deal with the supplier independently, the cost will much higher. (GM, Jinling store, Motel Chain)

What's more important is that standardized product makes flexible human resource management possible. Experienced general managers and assistant managers being transferred from high-performance hotels to newly-opening or poor-performance hotel is a common practice in the three companies. For most rotating manager, the management routine itself is not a challenge at all when transferred to another hotel, because what they need to do is just the same across all the hotels. As a result, the cost for training, maintaining and relocating management talents were lowered.

\section{3 Rapid Expansion}

In the hotel industry, hoteliers took multiunit organization form as an effective way to overcome the weakness of fragment and to acquire economies of scale. Some researchers already pointed out the effect of economy of scale on the efficiency and profitability rate in hospitality industry (Lafferty \& Fossen, 2001, Sinclair \& Stabler, 1997, Slattery, 1996).Top executives in the three companies knew that the more hotels they have, the more they can save from central purchasing, training and marketing; and the more markets they can penetrate, the more convenient service they can supply to their customers. In 2003, for example, Home Inn presented in only 4 cities with 10 hotels; in 2008, however, they already staged in 94 cities with 471 hotels. From 2003 to 2008, Jinjiang Inn and Motel Chain also successfully expanded from Shanghai area into 89 cities in 30 provinces and 43 cities in 19 provinces respectively.

Expediting the speed of expansion is one of the priorities in the three companies. According to CHA, in 2008, the rooms and hotels of Home Inn increased from 32,718 and 266 to 56,520 and 471, representing an increase of 73\% and 77\% respectively. The annual growth rate of Jinjiang Inn in 2008was 37\% in hotels and 31\% in rooms. In Motel Chain, the number was $29 \%$ and $35 \%$.

As the three companies open more and more hotels, the cost reducing effect is also intensified. The effect is mainly exhibited in the saving of centralized purchasing, training, marketing, financing, and overall management like quality control and distribution management. As the Director of Marketing from Home Inn said,

When we had only 4 hotels, we largely relied on some third-party reservation companies to fill our rooms. As the result of our fast development and customers' familiar to our brand, our independence improved increasingly, the third-party reservation companies also began lower their commission standard to our hotels.

Her colleague has the similar points,

Several years ago, I had to spend much of my time in finding and selecting the right candidate for the position of general manager. Now it is pretty easy. The internal recommendation from the general managers of our hotels contributed a great deal as we already had hundreds of hotels in operation. (Director of HR, Home Inn)

The occupancy in my hotel is $90.8 \%$ in the first six months this year. It is common in our system. Why can we keep it at such a high level? In my hotel, for example, the CRS will contribute $50 \%$ of the guests, including $14.8 \%$ of frequent guests. I mean, after Home Inn was recognized by customer, what I need to do every day is to fill up the other half of rooms (GM, Jixianglu store, Home Inn).

As the three companies keeping penetrating into new markets, the traveler can easily book a familiar hotel in almost all major cities in mainland China without worrying about the quality. As the Director of Marketing from Home Inn commented: 
"Talking about why our hotel was so popular among the guests, one of the most important reasons is convenience. We have presented in many cities and we still keep growing”.

Following the unit growth, the brand reputation also rises in the market. The more hotels the three brands open, the more benefits they can enjoy. Ingram wrote in 1996 that, "If a traveler has a pleasant stay at the Holiday Inn at Memphis, the Holiday Inn at Little Rock will get more business.”

\subsection{Continuous Innovation}

Innovation is one of the most mentioned words by the management from the three companies during our field work. The COO from Jinjiang Inn noted that:

"We keep innovating our products. We have already developed 4th generation products in 10 years. Our flagship hotel, Jinjiang Inn Xinhongqiao store is our first fourth-generation hotel. We have greatly improved the quality in this latest generation hotel".

The General Manager of Jinjiang Inn Xinhongqiao pointed out that:

"Our hotel is the first fourth-generation hotel. It is a big improvement In comparison with the third-generation product. The color of the room, for example, looks more comfortable. We also make the sound-proof effect of the wall better. The quality of mattress and bedding are as good as those of five-star hotels".

The other company, Motel Chain, launched its sixth-generation hotel in 2006 and was conceiving its seventh-generation hotel when the field work was being carried out. Home Inn does not declaim the launch of new-generation product. The product innovation, however, never stopped in Home Inn. The director of operations indicated that:

"Not so long ago, there was a space between mattress and frame and the floor in our guestroom. It is common that we found items left by guests under the frame. We even found 400 RMB on the floor. Now, the entire frame was re-devised so that there is not any space or gap between the frame and the floor".

In order to make their products more accessible, the three companies also made huge efforts in creating diversified distribution channels, which were obvious disadvantage of independent hotels in China. The customers from the three companies can make reservation easily through the call center, the Internet, and even the mobile phone. Furthermore, they launched their loyalty programs quickly after the customer size reached critical mass. The brand reorganization was also intensified mainly through advertisement in plane, airport, office building and radio. These practices, first introduced and implemented by the three companies, differentiated the three companies from other homegrown hotel companies in terms of marketing and distributing.

In the three companies, the management mode is also not a static one but a dynamic and evolutionary one. The mode was modified regularly through adding new contents and deleting of unsuitable ones, as result of learning by doing and learning by using (Dosi, 1988). In each modification, the management and service innovations created at one unit diffused quickly and effectively across all the other units, became parts of standard operation procedure and were practiced day after day by the management.

\subsection{Highlighting Quality Consistency}

The three companies have developed strict quality control system to maintain quality consistency. For example, Jinjiang Inn has set up six Operation Systems to support their unit hotels. The first and most important one is Quality Management Standard System. In China, many one-star and two star hotels also have similar standards but they do not execute them well. In order to make sure the standard will be implemented across all the hotels, the three companies have set up a management position named Region General Manager whose main responsibility is to examine the service quality and operation procedure of the hotels within his management region. The three companies have also enforced similar practices to make sure the quality standard will be executed well. The Director of Operations from Home Inn mentioned:

"One important reason why we can control quality well is that we require all the unit general managers should understand and practice all the service procedures first before they train their staffs. The general managers are capable of any job positions around the hotel. As the result, she or he is very sensitive to the quality change in all service encounters".

One general manager provided us with an example of quality examination in a Home Inn,

"We have a four-level check system for the rooms. After the employee finish cleaning the room, the foremen will check all the rooms. Then the housekeeping supervisor will check $60 \%$ of the finished room. The 
residential manager will check ten percentages. I will check five or six rooms every day. All the result will be

linked to the evaluation of staff work performance and their wages".

Except the daily quality examination executed by the foremen, the supervisor and the general manager, the three companies also implemented strict bi-annual or annual complete quality audit in every hotel. In each audit, about 400 items will be scrutinized and rated. Furthermore, secret shoppers also inspected each hotel 2 to 4 times each year. Those results constituted an important part of the performance of general manager, and then, related to their remuneration.

\subsection{Extensive Training}

Through the interviews it was found that there was extensive trainings at all levels in the three companies. In order to train employee effectively and efficiently, the three companies have established internal hotel colleges to train unit managers and supervisors.

For example, through intensive training at the Home Inn College, Home Inn made standard operation procedures a part of a there routine. The Director of Human Resources, Home Inn stated:

"Some of our general managers used to be the directors or department managers in four-star or five-star hotels. After they were selected and trained in the Home Inn College, they would receive a 21-course intensive training program which includes all the operational procedure and requirements in all the service position. They will not graduate from the college and get the certificate if they fail in any one of 21 exams".

Gang Cheng, one graduate from Home Inn College, now the General Manager of Oujieju Home Inn, described the training programs in detail:

"In Home Inn College, the general managers candidates will learn everything regarding guest service through a three-month training program. The College also has different levels of training programs for candidates of assistant GM, residential manager and housekeeping supervisor. All the managers will be trained 1-2 times in the College each year. --- ---, What we have learned will be used to train the front-line employees".

Jinjiang Inn and Motel Chain also have the similar training programs. Jinjiang Inns uses off-the-job training for general manager candidates which lasts two months. During this period, those who fail to meet the requirements will be taken off of the candidate list. In Motel Chain, all the general manager candidates are required to take part in a 6-week training programs. After becoming general managers, all 3 companies require managers to take annual training programs, which usually last 3-5 days.

At the front-line worker level, the supervisor and the general manager are responsible for training new employees. One housekeeper in Jinjiang Inn Huamu location told us before starting work she had received a 3-day orientation and training. The supervisor or the general manager will also train front-line employee every week in different stressing operations procedure, customer interaction and other skills.

\subsection{Indigenous Operation Practices}

Because homegrown companies understand local demand and supply better, they have the potential to carry out indigenous operation practices. In China’s economy hotel market, for example, some foreign brand hotels don't provide any food service for their customers. However, Chinese think breakfast is the most important meal of the day. The three companies know this and try their best to supply breakfast for guests. One of the Home Inn hotels stayed in for one night was converted from an office building which had no space for a kitchen or dining room. The general manager transformed two guest rooms on the second floor into a breakfast-only restaurant. It's simple but makes guests happy. As COO of Jinjiang Inn indicated,

"We understand our customers and our employees well. This is our strength when comparing with global brands".

The researchers found that the three companies practiced some indigenous operational strategies which included:

\subsection{Expanding through leasing}

In the hotel industry, luxury segment companies expand mainly through management contracts, however, economy segment companies prefer expanding through franchising. The research found that the three companies have developed a different expansion mode which takes into consideration their growth strategies in the Chinese context.

The CEO of Home Inn explained his opinion regarding their expansion: 
"If our ROI is $25 \%$, we can keep a $25 \%$ growth rate by ourselves in theory. But the pre-condition is that you can't own the hotel property or build a new hotel start from scratch, the leasing and franchising expand mode helps us grow at a brisk pace. We intentionally controlled the leasing/franchising ratio at 7:3 or 6:4 because today's franchising market is not a rational one and lack of good regulation. It is not a good time to enlarge the franchising ratio; however, we will look out and wait the opportunity".

In Home Inn's practice, all the hotels operated by themselves were leased or franchised instead of developed or owned by the company. Jijiang Inn and Motel Chain have the same strategy. Because leasing costs much less than ownership so they can operate more hotels taking into consideration their capital budget. Leasing also can be a trade off in regards to profit, control, risk and quality than "own-and-manage” and franchising modes. Bingfu Lu, CEO of Motel Chain commented on why they prefer leasing:

"The percentage of franchised hotels will be kept to a proper level because the legal system (for this relative new operation mode) in China is far from perfect. Thinking about the lack of trust in the society, our brand will suffer damage if we franchise too many hotels".

\subsection{Manage-chising}

The advantage of homegrown players is also mirrored in their superior knowledge about partners and other stakeholders. The researchers found a distinct niche employed by the three companies to operate their portfolios. It can be referred to as manage-chising. It's a blend of management contract and franchising agreement. The key difference between Manage-chising and ordinary franchising is that the ordinary franchiser is never involved in the daily operation of the franchised hotel. On the contrary, manage-chisers (the three companies) would send one full-time general manager to the owners' sites at manage-chisers' cost. This is necessary because most franchisees don't have any experience in hotel operation in China. In order to avoid brand damage and to support the franchisees, the three companies adapted the rules of franchising to make it work better in China.

As the COO of Jinjiang Inn mentioned,

"We provide more comprehensive support to the franchisees as compared with some foreign brands. We are deeply involved in the daily operation of our franchising hotels through the general managers. This is decided by China's specific context”.

\subsection{Age of workers}

The hotels in this study employ a different HR practices than those in star-rated hotels (which in general prefer young girls to staff their frontline positions). The three companies prefer to hire married women in their 30's and 40's, even if they have never worked in the hotel business. One general manager mentioned that married women will be more stable and less likely to jump to a competitor's hotel. The General Manger of the Pudong location of Motel Chain explained,

"If your labor turnover is high, your labor cost will rise, as you must spend a lot of time and energy in recruiting and training. If the turnover is maintained at a low level, it will help to keep the service quality consistent. This is why we prefer married, older candidates. Married women in their 30's or 40's are also more sophisticated than young girls. They know how to serve the guest and understand customer satisfaction”.

The three companies also recruit a lot of retired people at a lower cost. In one hotel of Home Inn, the researchers met a lady who was 50-years-old and was the chef and waitress in the small breakfast-only restaurant. She retired from a star-rated hotel and was recruited by the Home Inn hotel adjacent to her residence. She was experienced, affable and sophisticated. Eating in the small restaurant and talking with her is just like eating and spending time in a friend's home. Most of all, her base pay is 1,200RMB per month, only a little more than an inexperienced employees.

\subsection{Saolou (intensive promotion)}

In order to fill the rooms effectively, the three companies used some unique tactics. SaoLou which refers to visiting and contacting the potential customers near the hotel. It is a labor-intensive selling promotion effort. The common practice is, during the pre-opening period and following several months, hotel management would ask their employees, no matter whether you worked in front desk or restaurant, to visit nearby office buildings and hand out fliers. This will attract publicity and create sale opportunities. Hotel staff were also asked to distribute the fliers in adjacent shopping malls, local communities and in the streets. It is a simple way for promotion, but it works. At least 5 percent of the occupancy was contributed by Saolou in the three companies. 


\subsection{Duibiao (benchmarking)}

In order to improve operational efficiency, reduce costs and enhance service quality, the three companies applied a common management practice referred to as Dui Biao (internal benchmarking). The practice aims to force the general manager in each hotel to improve their performance continually. Every week or every two weeks, the corporate headquarters would send all the general managers an E-mail (or newsletters) which outlines their recent performance ranking system-wide. Performance indicators include both revenue data (room rate, occupancy) and cost data (mainly labor, energy and water). General managers can compare their hotel's performance with others'. Above all, the E-mail (or newsletters) will praise high-performance general managers and their practices and encourage other general managers to learn from those best practices.

\section{Discussion and Conclusions and Theoretical Contribution}

When examined independently, any one of the above-mentioned strategies such as innovative positioning, keeping costs low or extensive training, is not uncommon in the hotel industry. However, when these strategies are aggregated and integrated with indigenous operation practices, they bring huge competitive advantages to the three companies and allow them to not only outperform other domestic hotels but also successfully compete with their foreign counterparts. In the economy segment of the hotel industry the three companies and other similar companies like 7 Days Inn and Hanting Inns \& Hotels leave global giants Super 8 and Ibis far behind them (see Table 5). According to CHA, Super 8 and Ibis added 2,099 and 1,830 rooms respectively in 2008, however, 7 Days Inn and Hanting Inns \& Hotels, both established in 2005, added 10,709 and 10,724 respectively. With the help of the forgoing business level strategies the three companies created a competitive market niche which is characterized by higher quality and lower cost than their main competitors--- the 1 star hotels and 2 star hotels in China market.

As was mentioned before, the critical factor in the three companies' strategy is their unique positioning, which was also emphasized by many strategic scholars. Schendel and Hofer indicated that business level strategy copes with "How should a business position itself among its rivals in order to achieve its goals?”(1979). Hamel and Prahalad argued that "strategist's goal is not to find a niche within the existing industry space but to create new space that is uniquely suited to the company's own strengths" (1989). Porter also pointed out that the essence of strategy is "the creation of a unique and valuable position"(1996). In this study, the three companies successfully positioned themselves as servicing domestic travelers and executed a series of strategic activities, including keeping costs low, expanding quickly, consistent among others, to position themselves. When discussing the success of Southwest Airlines, Porter advanced that "Southwest has staked out a unique and valuable strategic position based on a tailored set of activities (1996)." Like Southwest, the three companies also based their positions on a tailored, contextual set of activities.

In the case of these 3 hotel companies, those activities were designed and performed in a specific operational environment. Firstly of all, when catering to a lower income level of domestic travelers, the ADR of the three companies were maintained around $200 \mathrm{RMB}$, roughly equal to $\$ 30$. Without strict cost controls, it would be impossible to make money at that rate. Secondly, to ensure survival in a market featuring excessive entry (Zhang, Qin, \& Li, 2000), the three companies had to keep innovating and expanded their size through cost-efficient methods such as leasing and manage-chising. Thirdly, for the purpose of differentiating their hotels from 1 star and 2 star hotels, they successfully maintained quality consistency through intensive training and comprehensive feedback systems. Finally, in the growth stage of the three companies, many ideas about positioning, hotel concept design and operation were learned from multi-nationals. In order to make imported concepts and techniques feasible in China market it was necessary to make adjustments to these practices.

From first glimpse, the strategies the three companies pursued are similar to what Kim and Mauborgne called "blue ocean strategy“ (Kim \& Mauborgne, 2004, Kim \& Mauborgne, 2005). But when they are scrutinized, it can be seen they are not identical to Kim and Mauborgne's concept. For example, Kim and Mauborgne believed that the blue ocean strategy will be pursued by only one, or at most, two players. In this case, however, there were at least 3 (or 5 if we take into account the similar strategies adopted by 7 Days Inn and Hanting Inns \& hotels) companies who have successfully executed the same strategies. Furthermore, in Kim and Mauborgne’s Blue ocean Strategy (2004), blue ocean strategist(s) mainly originated from incumbents, nevertheless, both Home Inn and Motel Chain are new comers.

\section{Limitations of the Study}

The main limitation of this paper lies in that most of the measurements regarding the strategies pursued by the three companies are gathered through subjective data collected in interviews rather than objective measures. Objective measures would have been preferable, however, as mentioned in the methods section, the context of this research made qualitative data more feasible. The combination of qualitative and quantitative methods would be helpful in the future. 
The main body of strategy studies in the hotel field primarily focus on organizations in developed economies such as the United States or West European countries. In spite of the rise of homegrown hotel companies in developing countries, especially in China and India, little research has been conducted at the business strategy level and the growth path for these companies. The present study is one of the first steps to fill the gap and can be regarded as a starting point for future studies. The practices pursued by these three fast-growing companies will be seen as helpful references for the managers in developed countries who want to enter emerging markets and for the managers in developing countries who are struggling in difficult but growing environments.

\section{References}

Ansoff, H. I. (1965). Corporate Strategy. New York: Mc-Graw Hill Company.

Barr, P. S. (2004) Current and potential importance of qualitative methods in strategy research. In Ketchen, David J \& Donald D Bergh, editors, Research Methodology in Strategy and Management.

Baum, J. A., \& H. A. Haveman H.A. (1997). Love thy neighbor? Differentiation and agglomeration in the Manhattan hotel industry. Administrative Science Quarterly, 42(2): 304-38. http://dx.doi.org/10.2307/2393922

Baum, J. A., \& Ingram. P (1998). Survival-enhancing learning in the Manhattan hotel industry. Management Science, 44(7): 996-1016. http://dx.doi.org/10.1287/mnsc.44.7.996

Baum, J. A., \& Mezias, S. J. (1992). Localized competition and organizational failure in the Manhattan hotel industry. Administrative Science Quarterly, 37(4): 580-605. http://dx.doi.org/10.2307/2393473

Brotherton, B. (2004). Critical success factors in UK budget hotel operations. International Journal of Operations and Production Management, 24: 944-69. http://dx.doi.org/10.1108/01443570410552135

Brotherton, B. \& Shaw, J. (1996). Towards an identification and classification of critical success factors in UK Hotels Plc. International Journal of Hospitality Management, $113-35$. http://dx.doi.org/10.1016/0278-4319(96)00014-X

Canina, Linda. (2008). The Importance of Research in Challenging Times. Cornell Hospitality Quarterly, 49(4): 342-43. http://dx.doi.org/10.1177/1938965508326881

China National Tourism Authority reports (2010) (2009) (2008) National Tourism Authority of China

Claver, Cortés, E., Azorín Molina, J. F., \& Pereira, M, J. (2007). The impact of strategic behaviours on hotel performance. International Journal of Contemporary Hospitality Management, 19(1): 6-20. http://dx.doi.org/10.1108/09596110710724125

Combs, Jim. (2008). Using Cases to Discover Theory: The Case of the Poland-Based Restaurant Operator. Cornell Hospitality Quarterly, 49(4): 450-53. http://dx.doi.org/10.1177/1938965508326542

Cui, G. \& Liu, Q. (2001). Emerging Market Segments in a Transitional Economy: A Study of Urban Consumers in China. Journal of International Marketing, 9(1): 84-106. http://dx.doi.org/10.1509/jimk.9.1.84.19833

Dev, C. S. (1989). Operating environment and strategy: The profitable connection. Cornell Hotel and Restaurant Administration Quarterly, 30(2): 8-13. http://dx.doi.org/10.1177/001088048903000205

Dev, C. S. \& Brown, J.R. (1990). Marketing Strategy, Vertical Structure and Performance in the Lodging Industry: A Contingency Approach. International Journal of Hospitality Management, 9(3): $269-82$. http://dx.doi.org/10.1016/0278-4319(90)90020-X

Dosi, G. (1988). Sources, procedures and microeconomic effects of innovation. Journal of Economic Literature, 26(3): 1120-71.

Eisenhardt, K. M. (1989). Building theory from case study research. Academy of Management Review, 14(4): 532-50.

Eisenhardt, K. M. (1989). Making fast strategic decisions in high-velocity environments. Academy of Management Journal, 32(3): 543-76. http://dx.doi.org/10.2307/256434

Eisenhardt, K. M. \& Graebner, M.E (2007). Theory Building From Cases: Opportunities and Challenges. The Academy of Management Journal, 50(1): 25-32. http://dx.doi.org/10.5465/AMJ.2007.24160888

Galbraith, C. \& Schendel, D. (1983). An Empirical Analysis of Strategy Types. Strategic Management Journal, 4(2): 153-73. http://dx.doi.org/10.1002/smj.4250040206

Geller, A. N. (1985). Tracking the critical success factors for hotel companies. Cornell Hotel and Restaurant 
Administration Quarterly, 25(4): 76-81. http://dx.doi.org/10.1177/001088048502500414

Gersick, C.J.G. (1994). Pacing strategic change: The case of a new venture. Academy of Management Journal, 37(1): 9-45. http://dx.doi.org/10.2307/256768

Gersick, C.J.G. (1988). Time and transition in work teams: Toward a new model of group development. Academy of Management Journal, 31(1): 9-41. http://dx.doi.org/10.2307/256496

Ghauri, P. (2004). Designing and Conducting Case Studies in International Business Research .In Marschan-Piekkari, R., Welch, C.A, editor, Handbook of qualitative research methods for international business. Northampton, MA: Edward Elgar Publishing.

Harrison, J.S. \& Enz, C.A. (2005). Hospitality Strategic Management: Concepts and Cases. Hoboken: Wiley.

Ingram, P. (1996). Organizational form as a mechanism for generating credible commitment: The evolution of naming strategy in the US hospitality industry. Strategic Management Journal, 17 : $85-98$. http://dx.doi.org/10.1002/smj.4250171007

Ingram, P. \& Baum, A.C. (1997). Chain Affiliation and the Failure of Manhattan Hotels, 1898-1980. Administrative Science Quarterly: 68-102. http://dx.doi.org/10.2307/2393809

Ingram, P. \& Inman, C. (1996). Institutions, Intergroup Competition, and the Evolution of Hotel Populations around Niagara Falls. Administrative Science Quarterly, 41(4): 629-58. http://dx.doi.org/10.2307/2393870

Kim, W. C. \& R. Mauborgne. 2004. Blue ocean strategy. Harvard Business Review, 82(10): 76-84.

Lafferty, G. \& Fossen, A. (2001). Integrating the tourism industry: problems and strategies. Tourism Management, 22(1): 11-19. http://dx.doi.org/10.1016/S0261-5177(00)00021-2

Meidan, Arthur \& Lee, Benjamin. (1982). Marketing strategies for hotels. International Journal of Hospitality Management, 1(3): 169-77. http://dx.doi.org/10.1016/0278-4319(82)90007-X

Miles, M. B. \& Huberman, A.M. (1994). Qualitative data analysis: An expanded sourcebook. Newbury Park, CA: Sage.

Miles, R. E. \& Snow,C.C. (1978). Organizational Strategy, Structure and Process. New York: McGraw-Hills.

Mintzberg, H. (1978). Patterns in strategy formation. Management Science, 24(9): 934-48. http://dx.doi.org/10.1287/mnsc.24.9.934

Okoroafo, S.C, Koh, A. Liu, Lulu. Jin, Xuemei, (2010). Hotels in China: A Comparison of Indigenous and Subsidiaries Strategies, Journal of Management Research, 2(1) 1-10

Olsen, M. D. (2004). Literature in strategic management in the hospitality industry. International Journal of Hospitality Management, 23(5): 411-24. http://dx.doi.org/10.1016/j.ijhm.2004.10.003

Olsen, M. D. \& Roper, A. (1998). Research in strategic management in the hospitality industry. International Journal of Hospitality Management, 17(2): 111-24. http://dx.doi.org/10.1016/S0278-4319(98)00012-7

Olsen, M. D., West, J. \& Tse, E (1998). Strategic management in the hospitality industry. New York: John Wiley \& Sons.

Pine, R. \& Pingshu, Qi. (2004). Barriers to Hotel Chain Development in China. International Journal of Contemporary Hospitality Management, 16,(1) 37-44 http://dx.doi.org/10.1108/09596110410516543

Porter, M. (1980). Competitive Strategy: Techniques for Analyzing Industry and Competitors. New York: The Free press.

Porter, M. (1996). What Is Strategy? Harvard Business Review, 74(6): 61-78.

Prahalad, C. K. \& Hamel, G. (1989). Strategic intent. Harvard Business Review, 67(3): 63-76.

Schaffer, J. D. (1987). Competitive Strategies in the Lodging Industry. International Journal of Hospitality Management, 6(1): 33-42. http://dx.doi.org/10.1016/0278-4319(87)90007-7

Schaffer, J. D. (1984). Strategy, organization structure and success in the lodging industry.International Journal of Hospitality Management, 3(4): 159-65. http://dx.doi.org/10.1016/0278-4319(84)90017-3

Schaffer, J. D. (1986). Structure and strategy: two sides of success. Cornell Hotel and Restaurant Administration Quarterly, 26(4): 76-81. http://dx.doi.org/10.1177/001088048602600420

Schendel, D. E. \& Hofer. C.W. (1979). Strategic management: A new view of business policy and planning. Boston: Little, Brown Boston. 
Sinclair, M. T. \& Stabler, M. (1997). The economics of tourism. London: Routledge. http://dx.doi.org/10.4324/9780203195437

Slattery, P. (1996). International development of hotel chains.In Kotas, R., Teare, R., Logie, J., Jayawardena, C., Bowen, J., editor, The International Hospitality Business. London: Cassell.

Snow, C. C. \& Hambrick, D.C. (1980). Measuring organizational strategies: some theoretical and methodological problems. Academy of Management Review: 527-38.

Stake, R. E. (2005). Qualitative case studies.In Denzin, N. K., Lincoln, Y. S., editor, Handbook of qualitative research. 3 ed. Thousand Oaks, CA: Sage.

West, J. J. \& Anthony, W.P. (1990). Strategic Group Membership and Environmental Scanning: Their Relationship to Firm Performance in the Food Service Industry. International Journal of Hospitality Management, 9(3): $247-67$. http://dx.doi.org/10.1016/0278-4319(90)90019-T

Whitla, P., P., Walters, G \& Davies, H.( 2007). Global strategies in the international hotel industry. International Journal of Hospitality Management, 26(4): 777-92. http://dx.doi.org/10.1016/j.ijhm.2006.08.001

Wong, K. K. \& Kwan, C. (2001). An analysis of the competitive strategies of hotels and travel agents in Hong Kong and Singapore. International Journal of Contemporary Hospitality Management, 13(6): $293-303$. http://dx.doi.org/10.1108/09596110110400490

Yin, R. K. (1994). Case study research: design and methods. Beverly Hills: Sage.

Zhang, H., Qin, Y, \& Li, X (2001). The Bases and implications of the Economy Hotels Developing in China. Journal of Guilin Institute of Tourism, 11(1): 34-38.

Zhang, H., Qin, Y. \& Li., X (2000). An In-Depth Thought about the Present State of Competition in China's Hotel Inudstry. Tourism Tribune, 15(3): 31-35.

Table 1. Top 10 Chinese Domestic Hotel Companies (year ending 2009)

\begin{tabular}{|c|c|c|c|c|}
\hline Ranking & Company & $\begin{array}{c}\text { Room } \\
\text { opened }\end{array}$ & $\begin{array}{l}\text { Hotels } \\
\text { opened }\end{array}$ & $\begin{array}{c}\text { Time of } \\
\text { established }\end{array}$ \\
\hline 1 & Shanghai Jinjiang International Hotels Company & 39,568 & 194 & 1983 \\
\hline 2 & Home Inn \& Hotels Management Inc. & 71,407 & 621 & 2002 \\
\hline 3 & JinJiang Inn Co., Ltd ${ }^{1}$ & 43,219 & 325 & 1996 \\
\hline 4 & Shanghai Motel Chain Co., Ltd & 33,948 & 191 & 2003 \\
\hline 5 & BTG-Jianguo Hotels \& Resorts & 17229 & 58 & $1982^{2}$ \\
\hline 6 & JinLing Hotels \& Resorts & 15839 & 64 & $1983^{2}$ \\
\hline 7 & Metropark Hotels Management Co. & 13435 & 45 & 1985 \\
\hline 8 & GuangDong Hotel Management Holdings Ltd. & 13583 & 48 & N.A ${ }^{3}$ \\
\hline 9 & 7 Days Inn Group & 33,165 & 330 & 2005 \\
\hline 10 & Hanting Inns \& Hotels & 27,301 & 238 & 2005 \\
\hline \multicolumn{5}{|c|}{$\begin{array}{l}\text { Source: Chinese Tourism Hotel Group Statistics 2009, China Tourism Hotel Association(CTHA); China } \\
\text { Economy Hotel Survey 2009, CHA. } \\
\text { Note: } 1 \text {. JinJiang Inn Company is a subsidiary of Shang Jinjiang International Hotels Company. We extracted the } \\
\text { JinJiang Inn's data from the mother company. } \\
\text { 2. The opening year of the first hotel managed by the company. } \\
\text { 3. The accurate established time is not available, but one of the hotels operated under GDH name opened as early } \\
\text { as } 1986 \text {. }\end{array}$} \\
\hline
\end{tabular}


Table 2. The Top 6 Economy Hotel Chains in China

\begin{tabular}{|c|c|c|c|c|c|c|c|}
\hline \multirow{2}{*}{ Company } & \multicolumn{3}{|c|}{ Total Rooms } & \multicolumn{3}{c|}{ Total Hotels } & Year \\
\cline { 2 - 7 } established
\end{tabular}

Source: China Economy Hotel Survey 2007, 2008,2009, China Hotel Association.

Table 3. Excerpts from Reduced Interview Transcripts*

\begin{tabular}{|l|}
\hline Interview with the General Manager of Oujieju Home Inn, Hongkou District, Shanghai \\
\hline Reduced description \\
\hline $\begin{array}{l}\text { Headquarter trained us in everything, including what to do and how to do. What you need to do is } \\
\text { simply follow these guidelines. } \\
\text { criteria. }\end{array}$ \\
\hline $\begin{array}{l}\text { For a general manager, ensuring the production and operation criteria achieved is the most } \\
\text { important work }\end{array}$ \\
\hline Every Tuesday all the employees will be trained on job. \\
\hline At least 30\% of checked-in guests were Home Inn Club member. \\
\hline $\begin{array}{l}\text { At least } 20 \% \text { of checked-in guest reservations originated through the call center and Internet } \\
\text { Reservation Platform. }\end{array}$ \\
\hline Every morning, the first thing I do was check the performance ranking of our hotel. \\
\hline You can do nothing without the Management System in the computer. \\
\hline $\begin{array}{l}\text { The area supervisor came to check comprehensively twice one month. The headquarter send } \\
\text { secret guests four times one year. }\end{array}$ \\
\hline Half the light bulbs in the corridor will be switched off in the late night. \\
\hline $\begin{array}{l}\text { Note: *The original transcripts and reduced transcripts were all in Chinese and translated into } \\
\text { english }\end{array}$ \\
\hline
\end{tabular}


Table 4. Top Ten International Hotel Brands in Beijing and Shanghai

\begin{tabular}{|c|c|c|c|}
\hline Hotel Company & Hotel Brand & Hotel Company & Hotel Brand \\
\hline \multirow{4}{*}{ Inter-Continental } & Inter-Continental & \multirow{3}{*}{ Choice Hotels } & Comfort Inn \\
\hline & Crowne Plaza & & Comfort Suites \\
\hline & Holiday Inn & & Quality Hotel \\
\hline & Holiday Inn Express & Best Western & Best Western \\
\hline \multirow{5}{*}{ Wyndham } & Wyndham & \multirow{7}{*}{ Starwood } & St. Regis \\
\hline & Ramada & & Westin \\
\hline & Howard Johnson & & Sheraton \\
\hline & Days Inn & & W hotel \\
\hline & Super 8 & & Aloft \\
\hline \multirow{5}{*}{ Marriott } & J.W. Marriott & & Le Méridien \\
\hline & Marriott & & Four Points \\
\hline & Ritz-Carlton & \multirow{3}{*}{ Carlson } & Regent \\
\hline & Renaissance & & Park Plaza \\
\hline & Courtyard & & Radisson \\
\hline \multirow{2}{*}{ Hilton } & Hilton & \multirow{3}{*}{ Hyatt } & Park Hyatt \\
\hline & Doubletree & & Grand Hyatt \\
\hline \multirow{5}{*}{ Accor } & Sofitel & & Hyatt Regency \\
\hline & Pullman & & \\
\hline & Novotel & & \\
\hline & Mercure & & \\
\hline & Ibis & & \\
\hline
\end{tabular}

